\title{
Study of Selected Textural Features Properties on Asbestos Roof Images ${ }^{* *}$
}

\begin{abstract}
This research concentrated on an assessment of the sensitivity of five selected textural feature groups focused on changes in contrast, brightness, sharpness, and rotation of image. The analyzed texture images were real samples of asbestos roofs. During the study, MaZda software was used for determining 259 different textural features. The obtained results were analyzed to indicate insensitive parameters while transforming the sample image. There were no textural features found in the received results, which were simultaneously resistant to all of the implemented changes.
\end{abstract}

Keywords: image texture, asbestos roof, image processing, orthophotomap, textural features

Received: 31 January 2017; accepted: 20 March 2018

* AGH University of Science and Technology, Faculty of Mining Surveying and Environmental Engineering, Krakow, Poland

** This paper was prepared within the scope of Dean Grant No. 15.11.150.418 


\section{Introduction}

The identification of asbestos materials is an important current issue in the European Union. The public interest is concerned about this material because of its pathogenic and carcinogenic properties [1]. Therefore, in accordance with Directive 1999/77/EC, there has been a total ban on the use of asbestos throughout the European Union since January 1, 2005. In addition, a disposal obligation of all asbestos materials is imposed through 2032.

The action that should be taken before the disposal of asbestos is its inventory throughout the whole country. Polish public administration units carry out an inventory of asbestos roofs based on the data collected during field studies; however, this method is time-consuming and expensive. Therefore, an international scientific community is conducting research on the indication of methods that could be helpful in asbestos detection [2]. The literature presents examples of the use of aerial and satellite imaging. This research was carried out on high-resolution satellite imagery [3-5] and hyperspectral data [5, 6-9]. The mentioned results are very interesting; however, access to good-quality data is not easy and involves high costs of data purchasing and processing. In contrast, the orthophotomap is a widely available source material for the whole territory of Poland. Therefore, an attempt to analyze the information recorded on orthophotomaps was made in terms of the discussed problem.

The imageries of roofs differ in texture depending on the building material that was used. It would be appropriate to examine high-resolution texture images to determine the characteristic textural features, which would allow for the identification of roof materials. The results presented in this work are focused on this problem.

It is possible to distinguish a very large number of texture parameters. These parameters may be affected by changes in contrast, brightness, sharpness, and rotation of image. Therefore, there is a need to examine the sensitivity of each texture feature to such changes. For example, Rudnicki [10] carried out such an experiment based on computer-generated textures. In the presented study, real samples of asbestos roofs were used.

\section{Data and Methods}

During the analysis, fragments of digital orthophotomap were used. They were made for the city of Bochnia in 2008. The available digital image presented the studied area using $5 \mathrm{~cm}$ ground pixels.

The first step of processing the orthophotomap was Principal Component Analysis (PCA) transformation made in Idrisi. This transformation reduced the RGB components of the imagery to one 8-bit panchromatic image (the first PCA component). This solution was chosen due to the software requirements in a further analysis. 
In the second step, two roof fragments were cut out; they represented two different types of asbestos-cement roofs: corrugated sheets - "eternit" and flat sheets - "karo." Using the Gimp program, both fragments were rotated and cut out in such a way that the characteristic texture lines were parallel to the sample base and the data filled the whole space of the image. As a result, an eternit sample of $108 \times 108$ pixels and karo sample of $100 \times 60$ pixels were obtained (Fig. 1).
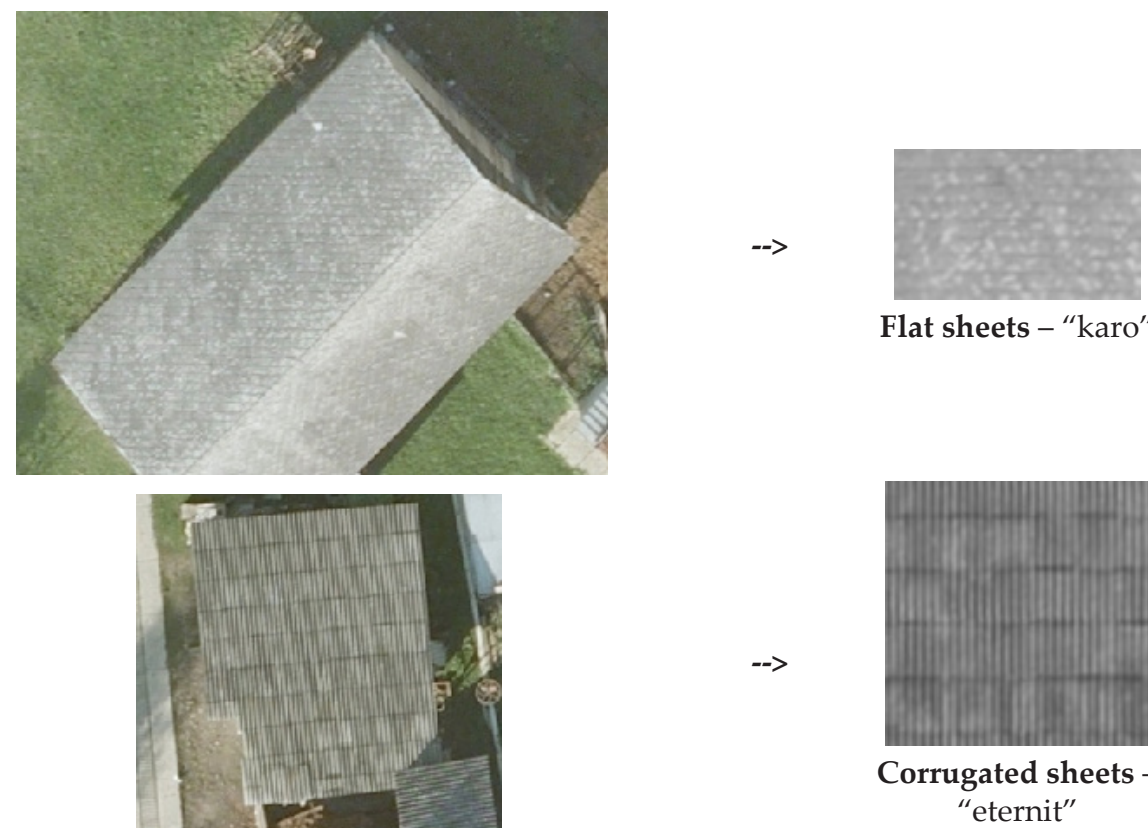

Flat sheets - "karo"

Fig. 1. Asbestos roofs selected for cut out of samples for further analysis (display scale - 1:300)

The analysis of both samples was then separated into two independent parts. The first experiment focused on an examination of the sensitivity of the textural features for changes in contrast, brightness, and sharpness of image. For this purpose, two sets of nine images were prepared: the original image (reduced to $75 \times 75$ pixels for the eternit and $40 \times 40$ pixels for karo samples) and the next eight images created by processing the original image in Gimp according to Table 1. The second approach was designed to research the sensitivity of the textural features to the rotation angle of the texture. For this purpose, two series of 24 images were generated for both asbestos samples. These images were cut out from the center of the original sample after successive rotations by $15^{\circ}$ angles. The new image sizes were $75 \times 75$ pixels for eternit and $40 \times 40$ pixels for karo. The new images sizes were adjusted so that the corner fragments of the rotated images were located in the area of the original asbestos samples. The maximum difference of the texture area between the rotated images and original one took place for a $45^{\circ}$-rotated angle and amounted to $\sim 10.3 \%$. 
Table 2 shows examples of the images used in the sensitivity analysis of the textural features while changing the texture rotation angle.

The prepared sets of images were loaded into the MaZda program [11]. This program allows us to calculate the quantitative textural features for each sample treated as a whole.

All of the images were described by 259 numerical parameters, which can be classified into five groups:

1) Nine histogram-based textural features: mean, variance, skewness, kurtosis, $1 \%$ percentile, $10 \%$ percentile, $50 \%$ percentile, $90 \%$ percentile, and $99 \%$ percentile;

2) Two hundred-twenty gray-level co-occurrence matrix-based parameters [12, 13]: angular second moment, contrast, correlation, sum of squares, inverse difference moment, sum average, sum variance, sum entropy, entropy, difference variance, and difference entropy; these parameters were calculated 20 times for $(d, 0),(0$, d), $(d, d)$, and $(d,-d)$, where distance $d$ can take the value of 1 to 5 ;

3) Twenty run length matrix-based characteristics [12, 14]: run length nonuniformity, grey-level nonuniformity, long-run emphasis, short-run emphasis, and fraction of image in runs; these parameters were computed four times (for horizontal, vertical, $45^{\circ}$, and $135^{\circ}$ directions);

4) Five absolute gradient-based parameters [12]: mean, variance, skewness, kurtosis, and percentage of pixels with nonzero gradient;

5) Five first-order autoregressive model characteristics $[11,15,16]: \theta_{1^{\prime}} \theta_{2^{\prime}} \theta_{3^{\prime}} \theta_{4^{\prime}}$ and $\sigma$.

The computed values of the textural features were transferred into Excel, where an analysis of the obtained parameter values was done. The percentage changes for the textural parameters caused by the image-processing operations were determined.

Table 1. Images used in sensitivity analysis of textural features while changing contrast, brightness, and sharpness

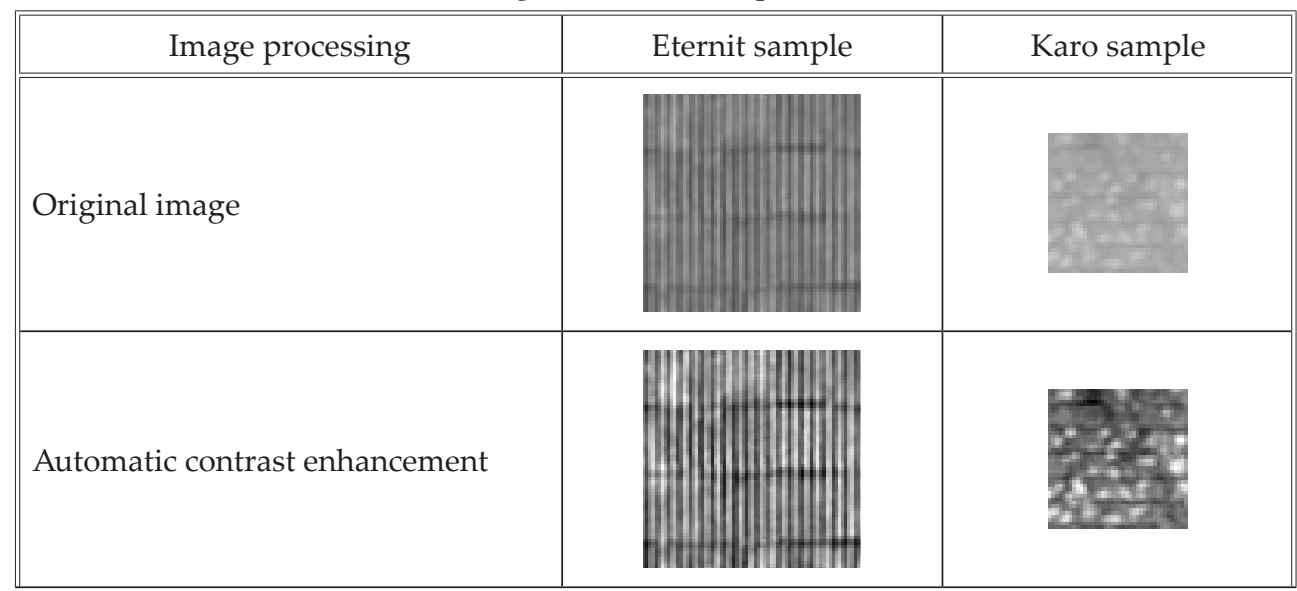


Table 1. cont.

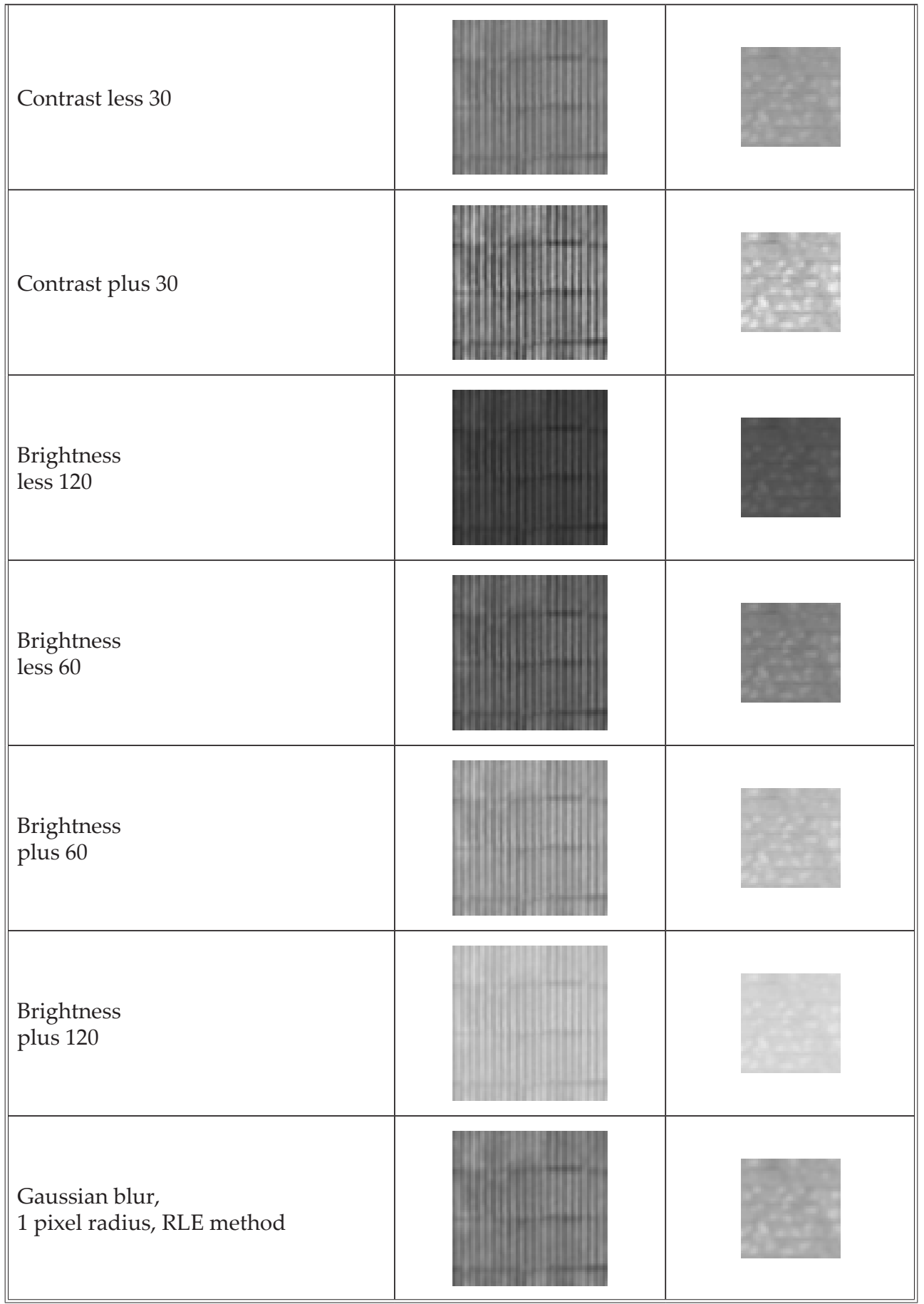


Table 2. Examples of images used in sensitivity analysis of textural features while changing texture rotation angle

\begin{tabular}{|c|c|c|c|c|c|c|}
\hline Sample & $\begin{array}{c}0^{\circ} \\
\text { rotation }\end{array}$ & $\begin{array}{c}45^{\circ} \\
\text { rotation }\end{array}$ & $\begin{array}{c}90^{\circ} \\
\text { rotation }\end{array}$ & $\begin{array}{c}165^{\circ} \\
\text { rotation }\end{array}$ & $\begin{array}{c}210^{\circ} \\
\text { rotation }\end{array}$ & $\begin{array}{c}345^{\circ} \\
\text { rotation }\end{array}$ \\
\hline Eternit & & & & & & \\
\hline Karo & & & & & & \\
\hline & & & & & & \\
\hline
\end{tabular}

\section{Analysis of Results}

The results were analyzed to indicate the textural features whose values did not differ significantly before and after transformation of the images. The parameters with the smallest changes were selected and presented in charts (Figs. 2-4). For the textural features determined in different directions and pixel distances, the minimum (min) and maximum (max) values of parameter are shown.

The percentage changes in the parameters due to changes in contrast are shown in Figure 2. The features calculated from the autoregressive model showed a low sensitivity to contrast changes: $\theta_{1^{\prime}}, \theta_{2}, \theta_{3^{\prime}} \theta_{4^{\prime}}$ and $\sigma$. When the automatic contrast enhancement was used, the change of these values did not exceed $0.1 \%$.

The difference in the skewness and kurtosis values did not exceed 3\% in either type of asbestos sample when compared to the original image. On the other hand, the change in variance for the automatic contrast enhancement reached up to $1538 \%$ for karo and $637 \%$ for eternit. Another percentage change is shown in Figure 2 that depends on the type of roof sample. Moreover, the automatic contrast enhancement in Gimp caused major changes in the parameters; the features determined from the autoregressive model as well as skewness and kurtosis are exceptions.

Rudnicki [10] stated that the textural features calculated from the run length matrix and three features from the gray-level co-occurrence matrix are not sensitive to changes in contrast. Our own results stand in opposition to this statement. These parameters changed values in relation to the values conducted from the original images.

The change in image brightness in both cases caused small percentage changes in the kurtosis and $\theta_{1}$ (Fig. 3). 
a)

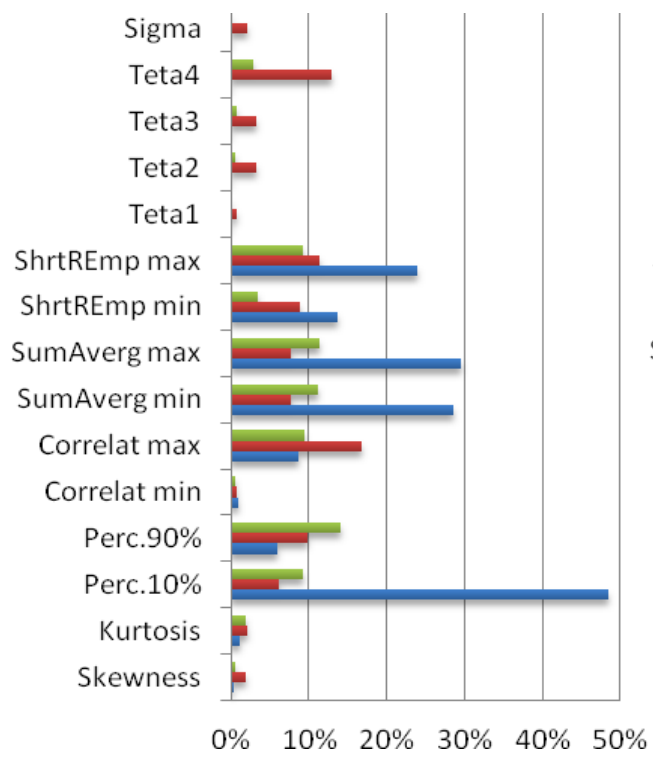

b)

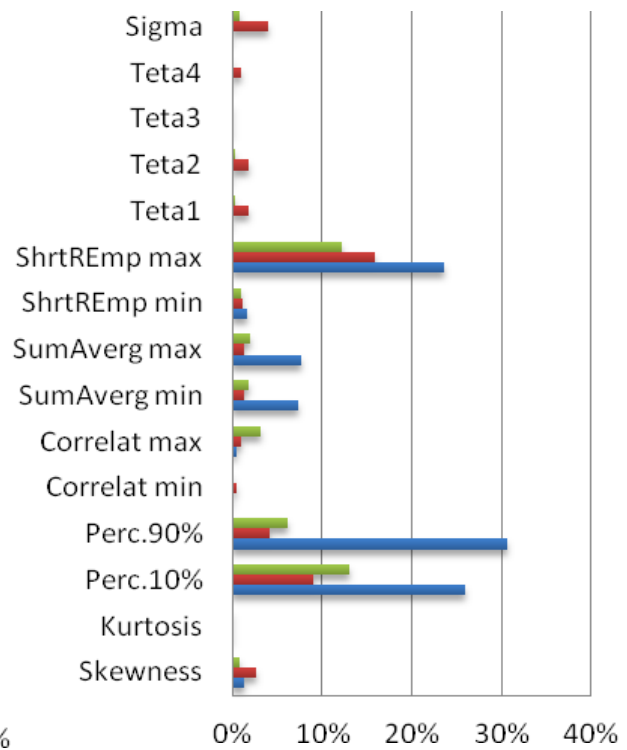

\section{n Contrast plus 30 - Contrast less 30 Automatic contrast stretch}

Fig. 2. Selected percentage changes of textural features caused by changes in image contrast: a) karo sample; b) eternit sample

a)

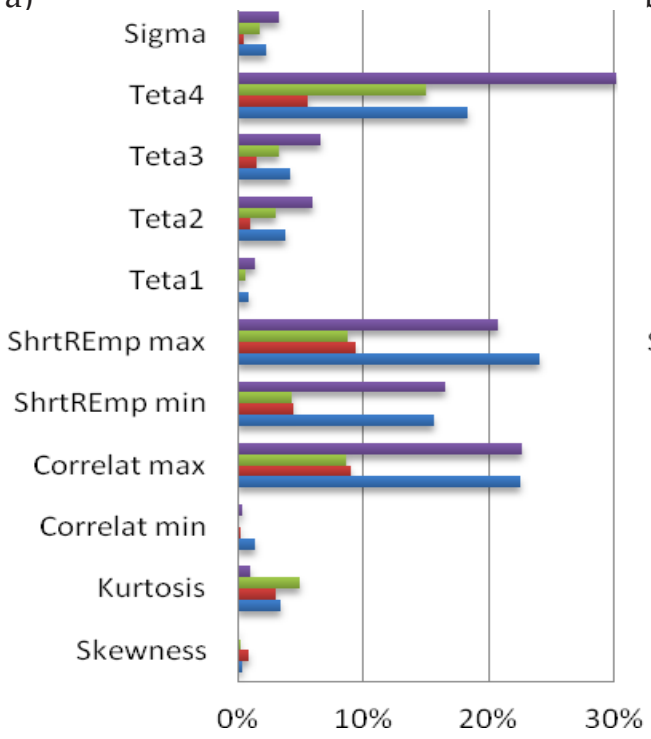

b)

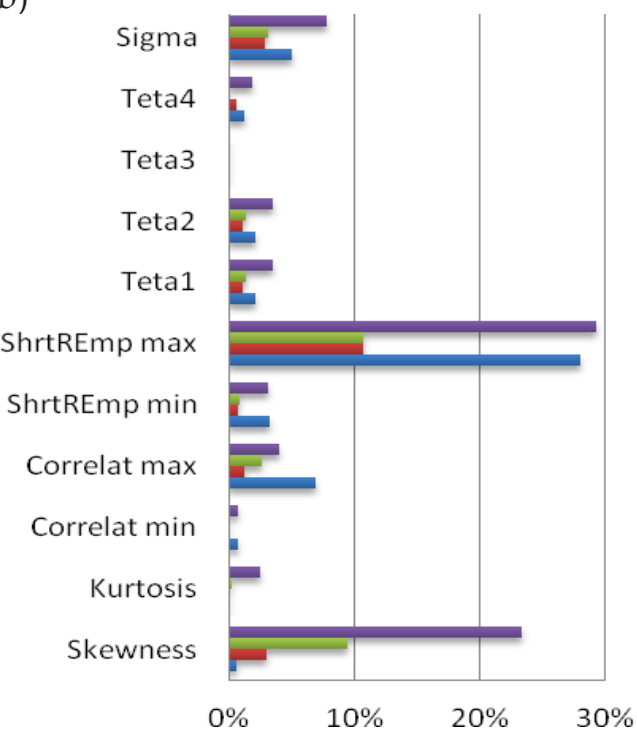

Brightness plus 127 Brightness plus 60

Brightness less $60 \quad$ Brightness less 127

Fig. 3. Selected percentage changes of textural features caused by change in image brightness: a) karo sample; b) eternit sample 
The blurry images (by the Gaussian function) had two textural features that were slightly dependent on image sharpness (Fig. 4). These parameters were mean brightness (mean) and summary average (SumAverg) calculated from the gray-level co-occurrence matrix. The difference in both values did not exceed $0.6 \%$ for either type of asbestos roof sample.

a)

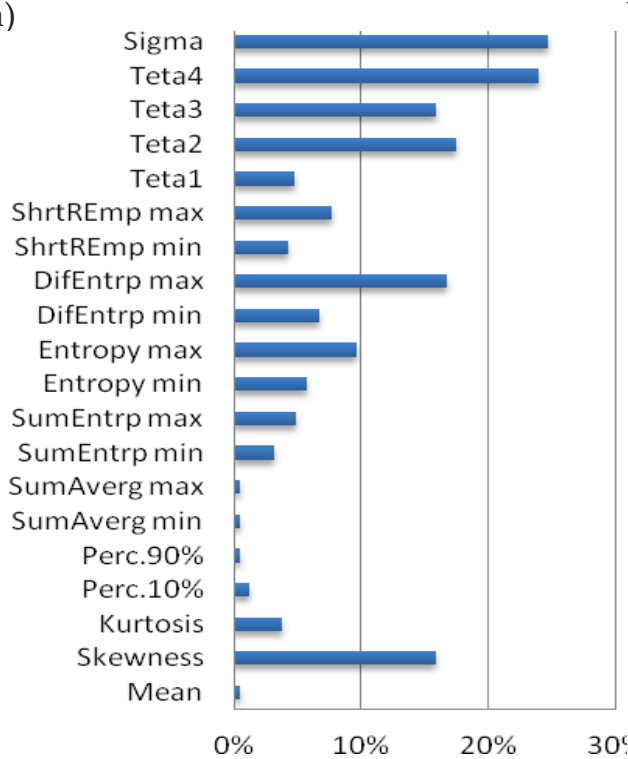

b)

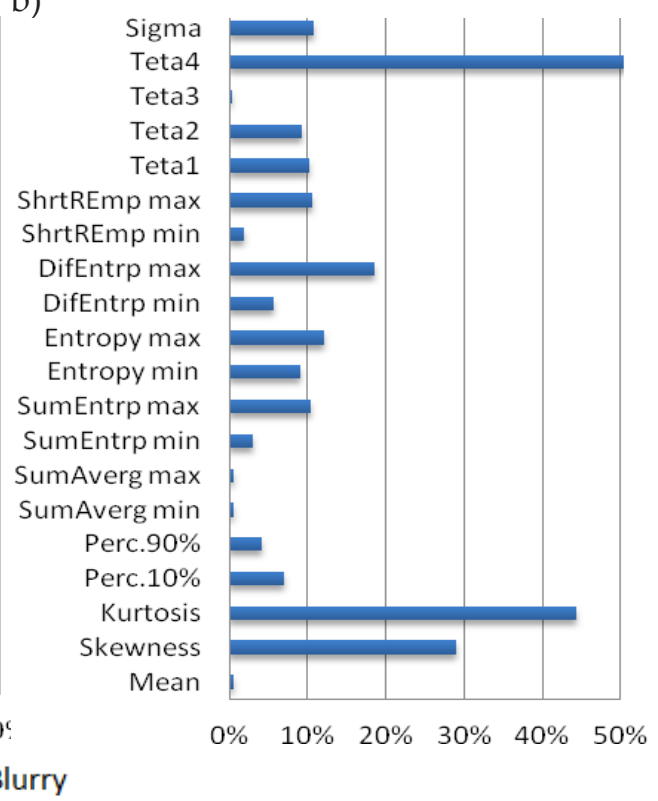

Fig. 4. Selected percentage changes of textural features caused by changes in image sharpness: a) karo sample; b) eternit sample

The texture of asbestos roofs can be oriented in any direction on orthophotomaps. A useful textural parameter should not be sensitive to changes in the rotation angle of the image. For both analyzed asbestos roof samples, the summary average (SumAverg) met this requirement. The percentage change of this value did not exceed 1.1\% (Fig. 5).

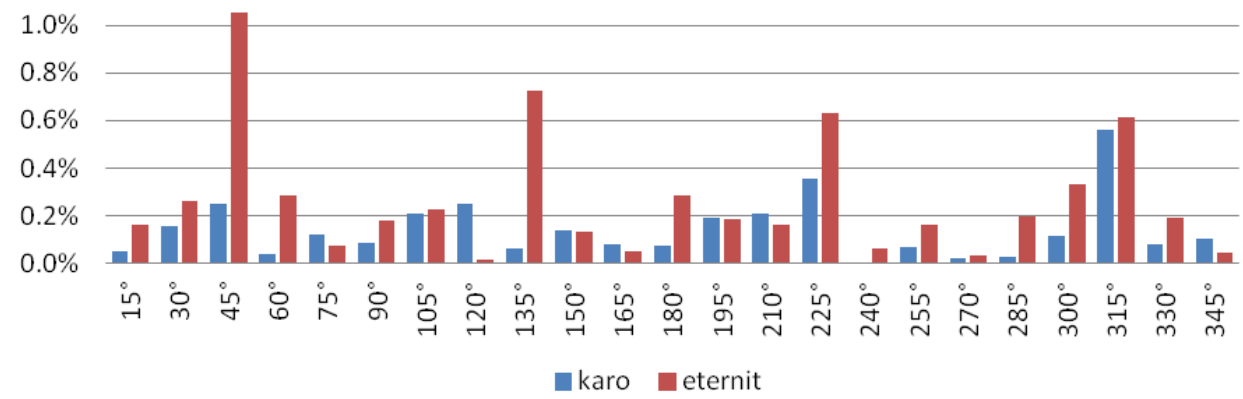

Fig. 5. Percentage changes of summary average (SumAverg $S(2,-2)$ ) depending on rotation angle of texture 


\section{Summary}

The conducted analysis showed that only a few textural features were not sensitive to image transformation. The changes in the samples contrast had little impact on the value of such parameters as the kurtosis, skewness, and features of the first-order autoregressive model $\left(\boldsymbol{\theta}_{1}, \boldsymbol{\theta}_{2}, \boldsymbol{\theta}_{3}, \boldsymbol{\theta}_{4}\right.$, and $\left.\sigma\right)$. In addition, the kurtosis and $\boldsymbol{\theta}_{1}$ were insensitive to changes in brightness. The value of the mean was almost constant while rotating and changing the sharpness of the image. Another interesting feature was the summary average (SumAverg), whose values did not change greatly due to rotation nor blurry texture. However, the value of this parameter was strongly correlated to the brightness and contrast of the samples.

To sum up, none of the studied textural features were sensitive to all image transformations simultaneously. Therefore, it seems that even the textural features highlighted above are not sufficient to identify the asbestos roofs on orthophotomaps. It may be appropriate to consider other texture characteristics in future studies.

\section{References}

[1] Bassani C., Cavalli R.M., Cavalcante F., Cuomo V., Palombo A., Pascucci S., Pignatti S.: Deterioration status of asbestos-cement roofing sheets assessed by analyzing hyperspectral data. Remote Sensing of Environment, vol. 109, 2007, pp. 361-378.

[2] Cilia Ch., Panigada C., Rossini M., Candiani G., Pepe M., Colombo R.: Mapping of Asbestos Cement Roofs and Their Weathering Status Using Hyperspectral Aerial Images. ISPRS International Journal of Geo-Information, vol. 4 (2), 2015, pp. 928-941.

[3] Galloway M.M.: Texture analysis using gray level run lengths. Computer Graphics and Image Processing, vol. 4 (2), 1975, pp. 172-179.

[4] Hajek M., Dezortova M., Materka A., Lerski R. (eds.): Texture Analysis for Magnetic Resonance Imaging. 1st ed. Med4publishing, Prague 2006.

[5] Haralick R.M.: Statistical and structural approaches to texture. Proceedings of the IEEE, vol. 67, 1979, pp. 786-804.

[6] Jain A.: Fundamentals of Digital Image Processing. Prentice Hall International, Englewood Clifs 1989.

[7] Krówczyńska M., Wilk E., Pabjanek P., Kycko M.: Hyperspectral Discrimination of Asbestos-Cement Roofing. Geomatics and Environmental Engineering, vol. 11, no. 1, 2017, pp. 47-65.

[8] Książek J.: Methods for detection of asbestos-cement roofing sheets. Geomatics and Environmental Engineering, vol. 8, no. 3, 2014, pp. 59-76.

[9] Osińska-Skotak K.: Zastosowanie technik teledetekcyjnych do inwentaryzacji cementowo-azbestowych pokryć dachowych. Teledetekcja Środowiska, vol. 51 (2014/2), 2014, pp. 73-83. 
[10] Pinho C.M.D., Silva F.C., Fonseca L.M.C., Monteiro A.M.V.: Intra-urban land cover classification from high-resolution images using the C4. 5 algorithm. The International Archives of the Photogrammetry, Remote Sensing and Spatial Information Sciences, vol. XXXVII, Part B7, 2008, pp. 695-699.

[11] Rudnicki Z.: Badania własności wybranych cech dyskryminacyjnych obrazów tekstur. Automatyka, t. 13, z. 3/1, 2009, pp. 959-969.

[12] Szabó Sz., Burai P., Kovács Z., Szabó G., Kerényi A., Fazekas I., Paládi M., Buday T., Szabó G.: Testing algorithms for the identification of asbestos roofing based on hyperspectral data. Environmental Engineering and Management Journal, vol. 13, issue 11, 2014, pp. 2875-2880.

[13] Szeszenia-Dąbrowska N., Sobala W.: Zanieczyszczenie środowiska azbestem. Skutki zdrowotne. Raport z badań. Oficyna Wydawnicza MA, Łódź 2010.

[14] Szczypiński P., Strzelecki M., Materka A., Klepaczko A.: MaZda-a software package for image texture analysis. Computer Methods and Programs in Biomedicine, vol. 94 (1), 2009, pp. 66-76.

[15] Taherzadeh E., Shafri H.Z.M., Mansor S., Ashurov R.: A comparison of hyperspectral data and Worldview-2 images to detect impervious surface. [in:] $4^{\text {th }}$ Workshop on Hyperspectral Image and Signal Processing: Evolution in Remote Sensing (WHISPERS), 2012: 4-7 June 2012, Shanghai, China, IEEE, 2012, pp. 1-4.

[16] Walker R.F., Jackway P.T., Longstaff I.D.: Recent developments in the use of the co-occurrence matrix for texture recognition. [in:] 13 $3^{\text {th }}$ International Conference on Digital Signal Processing, DSP97, July 2-4, 1997, Santorini - Hellas (Greece): Proceedings, ZEUS European Economic Interest Group, 1997, pp. 63-65.

\section{Badania własności wybranych cech teksturalnych na podstawie fragmentów obrazów dachów azbestowych}

Streszczenie: Przedstawione prace badawcze dotyczyły oceny wrażliwości wybranych pięciu grup cech teksturalnych na zmiany kontrastu, jasności, ostrości oraz obrotu obrazu. Obraz tekstury stanowiły rzeczywiste próbki dachów azbestowych. W trakcie badań korzystano z oprogramowania MaZda, które pozwoliło wyznaczyć 259 różnych cech teksturalnych. Przeanalizowano otrzymane wyniki pod kątem parametrów niewrażliwych na przekształcenia obrazu próbki. W uzyskanych wynikach nie znaleziono cech tekstury, które są równocześnie odporne na wszystkie czynniki powodujące ich zmianę.

Słowa

kluczowe: tekstura obrazu, dachy azbestowe 